\title{
Liggingsaspekte van spoorvervoereindpunte wat die winsgewendheid van goederespoordienste ondersteun
}

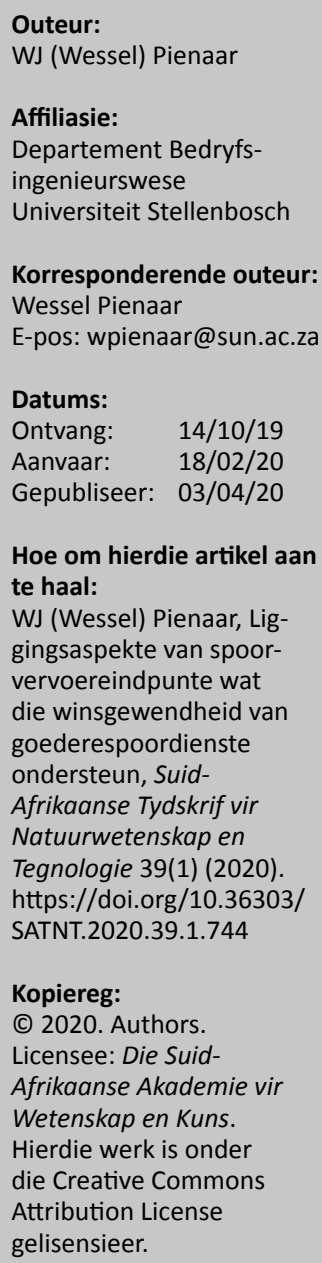

Hierdie artikel bied 'n oorsig van liggingsaspekte van spoorvervoereindpunte wat die lewering van winsgewende goederespoordienste kan ondersteun. Aangesien spoorvervoer tot vaste roetes beperk is en ' $n$ stasie-tot-stasie-diens eerder as ' $n$ diens van perseel tot perseel lewer, is die plasing van spoorvervoereindpunte en die uitleg van die spoornetwerk van deurslaggewende belang vir die suksesvolle bedryf van goederespoorvervoerdienste. Liggingsaspekte van losmaat-, grootmaat-, opry-afry- en intermodale eindpunte word bespreek. Die artikel beskou die invloed wat die veranderde rol van spoorvervoer sedert die ekonomiese deregulering van goederevervoer op die ligging van spoorvervoereind punte het, aan die hand van die drie mees bepalende faktore daarvan. Hierdie faktore is: (1) die verkeer se oorsprong- en bestemmingsplekke, (2) die verkeersomvang en (3) die aard van die eindpuntaktiwiteite. Ten slotte word die uitwerking van die uitleg van die spoornetwerk op die toeganklikheid van spoorvervoereindpunte oorsigtelik bespreek.

Trefwoorde: liggingsaspekte, spoorvervoereindpunte, winsgewendheid, goederespoordienste

Locational aspects of rail transport terminals that support the profitable supply of freight rail services: This article offers an overview of locational aspects of rail transport terminals that can enhance profitable freight rail operations. In view of the fact that rail transport is confined to fixed routes and that it provides a station-to-station service rather than a service from premises to premises, the placing of rail transport terminals and the layout of the rail network are of critical importance for the successful operation of freight rail services. Locational aspects of beak-bulk, bulk, roll-on roll-off and intermodal terminals are discussed. The article examines the effect of the changed role of rail transport since the economic deregulation of freight transport on the location of rail transport terminals by considering the three most pertinent determining features. These features are: (1) the places of origin and destination of the traffic, (2) the traffic volume and (3) the nature of terminal activities. Finally, the effect of the layout of the rail network on the accessibility of rail transport terminals is briefly discussed.

Key words: location aspects, rail transport endpoints, profitability, freight rail services

\section{Inleiding}

Hierdie oorsigartikel is die tweede van drie. Die vorige artikel het gehandel oor goederevervoermarksegmente wat belofte toon om winsgewend deur spoorvervoer bedien te word indien die aanbod daarvan doelmatig en doeltreffend geskied (Pienaar 2019). Hierdie artikel is gerig op die plasing van spoorvervoereindpunte om 'n goederespoorstelsel so toeganklik te maak dat dit kan bydra tot die winsgewendheid van goederevervoerdienste per spoor. Die volgende (laaste) aflewering handel oor die funksionele rol van spooreindpuntgeriewe om die suksesvolle vervoer van goedere per spoor te ondersteun.

\section{Studiebehoefte}

Die oogmerke van hierdie artikel is om 'n oorsig te gee van aangeleenthede wat die plasing van spoorvervoereindpunte onderlê in die goederevervoermarksegmente wat belofte toon om winsgewend deur spoorvervoer bedien te word. 


\section{Ondersoekmetode}

Die ondersoek is uitgevoer deur stede en vervoereindpunte in nywerheidslande te besoek waar spoorgoederevervoerbedrywighede op groot skaal plaasvind, en deur onderhoude en korrespondensie met verteenwoordigers van spoorgoederevervoeroperateurs te voer. Die ondersoeke ter plaatse is aangevul deur 'n literatuurstudie oor die onderwerp van die ondersoek. Altesaam 35 plekke op ses kontinente waar spoorvervoerbedrywighede plaasvind, is besoek. Die volledige lys plekke wat vir navorsingsdoeleindes besoek is, is in die vorige aflewering vermeld (Pienaar 2019:168-179).

\section{Agtergrond}

Die karweiding van goedere van een plek na 'n ander is 'n belangrike deel en gewoonlik die grootste koste-item van die bedryfslogistieke proses. Goederevervoer voeg waarde tot dié proses toe deur plek- en tydnut te skep. Pleknut is die waarde wat tot goedere toegevoeg word wanneer dit van 'n plek waar dit in 'n onbenutbare vorm of in oormaat voorkom, vervoer word na 'n plek waar dit tot 'n nuttige vorm verwerk word of waar dit relatief skaars is in verhouding tot behoeftes (d.w.s. waar daar 'n doeltreffende vraag na die goedere bestaan). Tydnut is die waarde wat toegevoeg word as goedere op die bestemde plek beskikbaar gestel word op die tyd wanneer dit vereis word vir gebruik of verbruik. Die vermoë van 'n vervoerstelsel om pleknut te skep hang ten nouste saam met die toeganklikheid daarvan. Toeganklikheid kan enersyds as 'n eienskap van 'n karweier en andersyds as 'n kenmerk van 'n bepaalde plek beskou word. Uit die oogpunt van 'n karweier is dit die vermoë om 'n diens tussen spesifieke fasiliteite te lewer en om fisies toegang tot sulke fasiliteite te verkry. As 'n kenmerk van 'n plek behels toeganklikheid die gemak waarmee dit bereik kan word - dit weerspieël die aantreklikheid van 'n plek as 'n oorsprong (hoe maklik dit is om elders te kom van daar af, in hierdie geval met spoorvervoer) of as 'n bestemming (hoe maklik dit is om daar te kom van elders af) (COTO 2017:ii).

Spoorvervoer is tot vaste roetes en eindpunte beperk en het daarom nie die buigsaamheid en toeganklikheid van padvragkarweiers nie. Spoorvervoer verskaf 'n stasie-totstasie-diens eerder as van perseel tot perseel tensy die kliënt 'n spoorsylyn by sy perseel het. As 'n perseel nie aan 'n spoornetwerk gekoppel is nie, moet padvervoer gebruik word om toegang tot die spoordiens te kry indien dit benodig word.

In spoorvervoer word die funksies van 'n eindpunt deur 'n stasie vervul. Dit staan dikwels ook as 'n treinstasie bekend, en wanneer slegs spoorvervoer ter sprake is, word gewoonlik bloot na 'n stasie verwys. In hierdie artikel word "eindpunt" en "stasie" sinoniem gebruik.

Generies gesproke is ' $n$ vervoereindpunt ' $n$ fasiliteit aan die einde van'n roete of waar verskillende roetes bymekaarkom, vertak of kruis; dit is met strukture en toerusting ingerig vir die laai, aflaai, transito-opberging en oordrag van goedere tussen voertuie in dieselfde vervoermodus of in verskillende vervoermodusse. "Eindpunt" beteken hier 'n fasiliteit waar goedere op- en afgelaai kan word, eerder as die einde van die spoorlyn self (RNE 2014:42).

'n Stasie aan die einde van 'n spoorlyn staan as 'n terminusstasie bekend, 'n stasie langs die looplyn as 'n onderwegstasie en 'n stasie waar meer as een looplyn ontmoet of kruis, as ' $n$ aansluitstasie. In Suid-Afrika is terminusstasies gewoonlik in kusstede, byvoorbeeld Kaapstad, Port Elizabeth, Oos-Londen en Durban; voorbeelde van groot onderwegstasies langs hooflyne in Suid-Afrika is Beaufort-Wes, Johannesburg, Kimberley en Pietermaritzburg, en voorbeelde van groot aansluitstasies is Beaconsfield (net suid van Kimberley), De Aar, Germiston en Ladysmith.

\section{Faktore wat die ligging van stasies bepaal}

Die ligging (of plasing) van eindpunte is van strategiese belang. Die belangrikste faktore wat die plasing van spoorgoederevervoereindpunte bepaal, is (1) die ligging van die oorspronge en bestemmings van die verkeer, (2) die verkeersomvang (wat die grootte en die aantal eindpunte bepaal) en (3) die aard van eindpuntwerksaamhede.

\section{Die ligging van die oorspronge en bestemmings van die verkeer}

Voor die opkoms van padvervoer het ekonomiese aktiwiteite dikwels rondom spooreindpunte plaasgevind veral sakegebiede in stede het meesal rondom die spoorstasies ontwikkel. Namate die padgoederevervoerbedryf gegroei en padinfrastruktuur uitgebrei en verbeter het, het die oorheersing van spoorvervoer geleidelik getaan en het die behoefte aan baie spoorstasies afgeneem, veral in nywerheidslande (Rodrique 2017:194). Sedert die ekonomiese deregulering van goederevervoer het die sosioekonomiese diens en verpligtinge van spoorgoederevervoeroperateurs as algemene karweiers in nywerheidslande plek gemaak vir kontrakdienste. Passasierspendelvervoer het wel 'n owerheidsbeheerde sosio-ekonomiese diens gebly.

Passasierstasies, veral pendelstasies waar baie passasiers se ritte begin en eindig, is oor die algemeen in stedelike gebiede geleë. Die omliggende grondgebruikpatrone is mensvriendelik, terwyl spoorgoedere-eindpunte toenemend uit digbevolkte stedelike liggings verskuif is.

Passasierstreine word meesal as eenheidstreine bedryf en bly so saamgestel soos wat hulle is. Dit vereis dus minder rangeerbedrywighede en opstelwerwe, indien enige. In teenstelling daarmee moet spoorgoedere-eindpunte, met uitsondering van eenheidstreineindpunte, aansienlike rangeeraktiwiteite kan huisves. Dit vereis afsonderlike rangeer- en opstelwerfgeriewe. Die enorme grondop- 
pervlaktes wat vir spoorgoedereaktiwiteite by eindpunte in digbevolkte stedelike gebiede nodig is, word ervaar as (1) 'n relatief ondoelmatige vorm van stedelike grondgebruik; (2) 'n bron van eksterne kosteskepping weens geraas, onooglikheid en dikwels lugbesoedeling, wat as mensonvriendelik beskou word; (3) 'n belemmering vir die voorsiening van aaneenlopende straatnetwerke; en (4) 'n hindernis in die weg van toegang tot stedelike geriewe, die beweeglikheid van stedelinge en sosiale samesyn (Pienaar 2016:254).

Die onversoenbare diens- en bedryfskenmerke van passasiers- en goederespoorstelsels lei daarom tot die ruimtelike skeiding van passasiers- en goedere-eindpunte. Hoewel hulle meesal toegang tot dieselfde spoornetwerk deel, bedien hulle heeltemal verskillende marksegmente. Deesdae is dit blote toeval as passasiers- en goedereeindpunte naby mekaar lê. Anders as passasierstasies hoef goederestasies nie in digbevolkte gebiede geleë te wees nie. Omdat goederestasies 'n groot grondoppervlakte vir opstelwerwe en die opberg van goedere (die loonvrag) vereis, is dit meer waarskynlik dat goedere-eindpunte in oop, onbeboude gebiede geleë sal wees. Wat grootmaatgrondstowwe betref, sal goedere-eindpunte byvoorbeeld naby die produksiebron wees waar hulle as die vertrekeindpunt dien vir die grondstowwe wat na markte vervoer moet word (Rodrique 2017:192).

Die konvensionele losmaatgoedere-eindpunte, met hul behoefte aan meervoudige sylyne waarop treinstelle saamgestel en trokke gelaai en ontlaai kan word - 'n proses wat dikwels dae duur en omvangryke spoorkapasiteit in die eindpunt beset - het bykans oorbodig geword. Gevolglik is 'n kenmerk van spoorgoederestelsels deesdae dat die aantal stasies, depots, werwe en haltes verminder word. Deur ontvangs en aflewering van goedere by minder maar groter stasies te konsentreer, kan spoorvervoeroperateurs enersyds afstandsvoordele behaal deur langer ritte, en andersyds digtheidsvoordele behaal deur die groter benutting van rollende materiaal en die intensiewe gebruik van groot eindpunte.

Langafstandpadvervoer raak al hoe duurder weens stygendebedryfskosteenalhoemeerpadverkeersophopings. Talle langafstandversenders besef die voordele daarvan om spoorvervoer na 'n niestedelike ligging naby hul markte te gebruik. By so 'n ligging word trokvragte in kleiner besendings verdeel en dan per padvoertuig oor korter afstande na hul eindbestemmings, wat meesal in stedelike gebiede is, versprei.

\section{Verkeersomvang en die grootte van eindpunte}

Goederestasies kan volgens grootte in vier groepe verdeel word. Daar is (1) spoorweghaltes, (2) klein goederestasies, (3) middelslaggoederestasies en (4) groot goederestasies (Palmer 2011:1; Pienaar 2016:252; Rail yard 2016; Transnet School of Rail 2014:14). Hulle word hier onder bespreek. Spoorweghaltes is die kleinste stasies en het gewoonlik nie personeel nie of baie min personeel, en min of geen geriewe nie. Goederetreine sal net stilhou wanneer 'n enkele item (of 'n klompie items) wat per hand hanteer kan word, daar op- of afgelaai moet word, byvoorbeeld possakke, pakkies en draagbare houers (die spreekwoordelike "melkkan").

Spoorweghaltes kom net in lande voor waar goederspoorvervoer nog as 'n sosio-ekonomiese diens gelewer word. Haltes verg nie bykomende grondoppervlakte nie omdat hulle binne die gewone grondreserwe van 'n looplyn gehuisves word.

Klein goederestasies is gewoonlik geleë op taklyne of waar taklyne by 'n hooflyn aansluit. Wanneer 'n deel van ' $n$ klein passasierstasie vir die op- en aflaai van goedere gebruik word, kan dit die laaigebied of laaiplek genoem word; dit het gewoonlik sy eie toegang vanaf 'n openbare pad. Daar is dikwels geen geriewe vir die op- en aflaai van goedere nie en die versender of ontvanger moet dan sy eie hanteringstoerusting reël. Klein goederestasies se oppervlaktes oorskry gewoonlik nie meer as vyf hektaar nie.

Middelslaggoederestasies het gewoonlik 'n opstelwerf met rangeersylyne sodat treine verdeel kan word tussen (1) die verskillende plaaslike laai- en sorteersylyne, (2) die private sylyne, wat na die stasie toe kan lei, en (3) die looplyn. As sodanig vervul dit die funksie van 'n klein spoorwegnodus. Middelslaggoederestasies se oppervlaktes beslaan gewoonlik tussen 20 en 40 hektaar.

Groot goederestasies sluit gewoonlik die volgende werfkomponente in: (1) 'n ontvangswerf (aankomswerf), (2) 'n oordrag- en rangeerwerf, (3) 'n herstel- en instandhoudingswerf, (4) 'n lokomotiefdepot, (5) 'n opstelwerf en in sommige gevalle ook 'n eenheidstreinsylyn, en (6) 'n vertrekwerf. Groot goederestasies se oppervlakte beslaan gewoonlik meer as 150 hektaar.

\section{Ligging van spoorgoederevervoereindpunte volgens werksaamhede}

Spoorgoederevervoereindpunte kan volgens werksaamhede of funksies in vier breë klasse verdeel word: (1) losmaateindpunte, (2) grootmaateindpunte, (3) opry-afryeindpunte en (4) intermodale eindpunte (Pienaar 2016:252254; Rail yard 2016; Rickett 2013:11-36; Rodrique 2017:192197; Transnet School of Rail 2014:5-17).

\section{Ligging van losmaateindpunte}

Losmaateindpunte kan by enigeen van drie plekke geleë wees: (1) langs 'n passasierstasie (gewoonlik 'n klein of middelslaggoedere-eindpunt langs die platforms aan die wegkant, soos gesien van die stasiegebou); (2) afsonderlik van die geassosieerde passasierstasie op een van die laaisylyne wat daarvandaan lei; of (3) as 'n goedere-eindpunt op 'n private sylyn (meesal 'n groot goedere-eindpunt onder onafhanklike eienaarskap) wat nie regstreeks met enige spesifieke passasierstasie verbind is nie. 


\section{Ligging van grootmaateindpunte}

Hierdie spooreindpunte is by primêre produksiepunte (meesal myne, olieraffinaderye en graansuiers) en invoerhawens geleë waarvandaan grootmaatgrondstowwe na sekondêre vervaardigingsaanlegte gekarwei word (d.w.s. fabriekeen verwerkingsaanlegte), of nagrootmaateindpunte by uitvoerhawens en tenkwerwe by petroleum- en chemieseproduk-verspreidingsdepots. Grootmaateindpunte by die vertrek- en bestemmingspunt is gewoonlik op 'n private sylyn in 'n onbeboude gebied geleë.

\section{Ligging van opry-afry-eindpunte}

Opry-afry-eindpunte is gewoonlik by ' $n$ in- of uitvoerhawe en op private sylyne by 'n voertuigvervaardigingsaanleg en ' $n$ streekvoertuigverspreidingsentrum geleë. Hoewel opstelwerwe nie by opry-afry-eindpunte nodig is nie, vereis hierdie eindpunte 'n groot parkeergebied om die loonvragvoertuie te akkommodeer, veral by streekverspreidingsentrums, wat gewoonlik as versamelwerwe dien vanwaar die streek se kleinhandelsafsetpunte bedien word. Streekvoertuigverspreidingsentrums is gewoonlik weg van sentrale sakegebiede en digbevolkte gebiede geleë waar daar voldoende grondoppervlakte vir die eindpunte se persele beskikbaar is en van waar hulle 'n sentrale toegangsverbinding per pad het met die afleweringsgebied wat hulle bedien. ' $n$ Voorbeeld hiervan is die streekvoertuigverspreidingsentrum by Kaalfonteinstasie naby Kempton Park in Gauteng.

\section{Ligging van intermodale spooreindpunte}

Intermodale eindpunte is gewoonlik by die volgende drie soorte plekke geleë: (1) hawens, (2) aansluitstasies en (3) lokuspunte in groot nywerheidsgebiede, weg van sentrale sakegebiede en digbevolkte gebiede.

Hawens: Intermodale eindpunte kan deel wees van ' $n$ hawefasiliteit (aankaai- of nabykaai-sylyngeriewe) waar die goedereoordrag tussen treine en skepe plaasvind. Op aankaai-sylyne kan goedereoordrag regstreeks tussen treine en skepe plaasvind, terwyl goedereoordrag op nabykaai-sylyne via 'n opberggerief plaasvind. Behouering het die produktiwiteit van spooreindpunte aansienlik verbeter, aangesien dit die vinnige laai, aflaai en oorlaai van die vrag moontlik maak. Hierdie toename in produktiwiteit word behaal deur (1) goeie toegang tot ' $n$ hawe, (2) hanteringspoorlyne wat parallel met die houerkaaikant loop, (3) gesteun deur geoutomatiseerde hanteringsbedrywighede op die kaai om aan die vragoordragvereistes van moderne intermodale spoorbedrywighede te voldoen.

Intermodale eindpunte vereis minder maar langer spoorlusse as losmaateindpunte. Sulke langer spoorlusse verg kapitaalinvestering in geplaveide platforms en oppervlakke vir houerhanteringstoerusting en opbergingsruimte vir houers. Die uitleg hiervan vereis 'n relatief smal, langwerpige perseel wat tot 50 hektaar kan beslaan. Dit bring meermale mee dat seegebied aanliggend aan die hawe vir die huisvesting van so 'n nuwe intermodale eindpunt drooggelê moet word en dat verlate ruimtes by sulke hawens ontstaan waar losmaateindpunte voorheen geleë was. Hierdie ontruimde gebiede is gewoonlik vir herontwikkeling beskikbaar. Weens die grootte van sulke verlate ruimtes, wat tot 200 hektaar kan beslaan, en hulle nabyheid aan sakegebiede en die seefront gaan die herontwikkeling daarvan gewoonlik gepaard met veranderde en mensvriendelike grondgebruike, byvoorbeeld opbloeiende toeristeaantreklikhede, konferensiesentrums, luukse hotelle en eksotiese behuisingskomplekse.

Suid-Afrikaanse voorbeelde van plekke waar sulke herontwikkelings plaasgevind het as gevolg daarvan dat intermodale eindpuntgeriewe elders ingerig is, is die hawens van Durban en Kaapstad.

Aansluitstasies: By hierdie eindpunte word trokke en trokstelle tussen onverenigde houertreine en losvragtreine gerangeer, en daar kan verkeersinteraksie met padvervoer wees. Aansluitstasies is dus toegerus met redelik groot rangeerwerwe en dikwels ook opstelwerwe.

Lokuseindpunte: Alleenstaande binnelandse fokuseindpunte in nywerheidsgebiede is meesal vir padgoederevervoer toeganklik, met elke spooreindpunt wat 'n markgebied van omtrent een dag se padgoedere-retoerrit vanaf die eindpunt dek. Lokus-eindpunte kan verbind wees met private spoorsylyne (wat klein sylyne vir ligte houerverkeerbewegings, groot sylyne vir lang dog onverenigde houertreinstelle en/of volledige houereenheidstrein-sylyne kan insluit).

By intermodale spooreindpunte wat slegs eenheidstreine ontvang, is daar geen behoefte aan 'n opstelwerf nie. Intermodale eindpunte wat wel onverenigde houertreine ontvang, het self ook weinig behoefte aan rangeerwerk, want dit is veel makliker om houers elektronies op te spoor en hulle met meganiese hanteringstoerusting na ' $n$ ander voertuig of opslagposisie te verskuif as om 'n trein te verdeel en die houertrokke te rangeer. Dus word opstelwerwe, waar hulle ook al benodig word, dikwels onafhanklik van die intermodale spoorwerf bedryf en is hulle elders geleë.

\section{Toeganklikheids- en mobiliteits- funksie van die spooruitleg ${ }^{1}$}

Die spoorlyne wat deel van 'n spoornetwerk uitmaak, kan in dalende orde gerangskik word volgens verkeersvolume, roeteafstand en die mobiliteit (beweeglikheid) wat verskaf word. Hierdie drie kenmerke is nóu verwant. Let op dat 
mobiliteit en toeganklikheid omgekeerd verwant is - 'n spoorlyn wat deurgaans goeie mobiliteit verskaf, bied swak toeganklikheid aan individuele verskepings- en ontvangspunte, en andersom.

Spoorlyne word verdeel in looplyne (of deurlyne) en sylyne. Looplyne word verdeel in hooflyne, taklyne en toegewysde eenheidstreinlyne, terwyl sylyne in uitwykspore, doodloopsylyne en werflyne verdeel kan word.

Hooflyne vorm die deurroetes of hoofroetes tussen stede, groot dorpe en belangrike konsentrasies van ekonomiese aktiwiteit. Terwyl dit hierdie plekke van stasie tot stasie verbind, vul hooflyne primêr 'n funksie van langafstandmobiliteit, en maak daardeur die belangrikste are van die netwerk uit waaraan taklyne en sylyne verbind word. Om kapasiteitsredes het die hooflyne veral in nywerheidslande minstens 'n dubbelspoor en dikwels meervoudige parallelle spore. Hooflyne word tipies teen hoër snelhede bedryf as ander lyne en word in die algemeen volgens 'n hoër standaard gebou en in stand gehou as lyne laer in die hiërargie.

Taklyne is sekondêre spoorlyne wat van hooflyne aftak. Ofskoon taklyne 'n mobiliteitsfunksie vervul (al is dit minder uitdruklik as by hooflyne), vervul hulle ook 'n streekstoegangsfunksie. Hoewel baie taklyne nie op sigself winsgewend is nie, is hulle dikwels noodsaaklik om hooflyne ekonomies lewensvatbaar te help maak. Baie kort taklyne staan as blindespore bekend. 'n Blindespoor bied spoortoegang tot ' $n$ bestemming wat te klein is om die verlegging van roete van die naaste verbygaande deurlyn sodat dit deur daardie bestemming gaan, ekonomies te regverdig, maar dit regverdig wel 'n kort aftakeindpuntspoorlyn wat toegang tot die spoornetwerk verleen. 'n Blindespoor kan ook topografies só afgeslote wees dat die bou van 'n deurlyn nie tegnies haalbaar is nie. ' $n$ Voorbeeld van laasgenoemde is die eindpuntspoorlyn wat van Hartenbos-stasie aftak na Mosselbaai-stasie, wat op 'n skiereiland geleë is.

Toegewysde eenheidstreinlyne is lyne wat vir uitsluitlike gebruik deur eenheidstreine bedoel is - gewoonlik grootmaat-eenheidstreine (Pienaar 2018:5). Hierdie lyne verbind fasiliteite wat op private sylyne geleë is. As deel van uitvoerverkeer loop hulle gewoonlik van 'n sylyn by 'n ontginningsplek af na 'n sylyn by 'n uitvoerhawe. SuidAfrikaanse voorbeelde hiervan is die $861 \mathrm{~km}$ lange SishenSaldanha-ysterertslyn, waarop eenheidstreine met 300 of meer oop trokke elk bedryf en jaarliks ongeveer 59 miljoen tonerts vervoer word, en die $580 \mathrm{~km}$ lange BroodsnyersplaasRichardsbaai-steenkoollyn, waarop eenheidstreine met tot 200 oop trokke elk bedryf en jaarliks ongeveer 80 miljoen ton steenkool vervoer word (Havenga \& Simpson 2016:320). As deel van invoerverkeer is dit gewoonlik van ' $n$ sylyn by 'n invoerhawe af na 'n sylyn by 'n verwerkingsaanleg.

'n Sylyn is enige ander lyn as ' $n$ looplyn. Sylyne kan verdeel word in uitwykspore, doodloopsylyne en werfspoorlyne.
Sylyne is laespoed-spoorseksies en het dikwels ligter spore wat gepas is vir die stadiger en ligter verkeer, met net enkele of geen sinjale nie.

Uitwykspore (of lusse) is seksies spore wat parallel aan 'n looplyn lê en aan beide punte deur uitdraaiwissels verbind word aan die looplyn. Uitwykspore laat treine wat in teenoorgestelde rigtings beweeg, toe om by mekaar verby te gaan; maak dit moontlik vir vinnige en hoëvoorrangtreine om stadiger of laervoorrangtreine wat in dieselfde rigting gaan, verby te steek; en word gebruik om 'n lokomotief in staat te stel om óm 'n trein te beweeg. Uitwykspore is belangrik vir die doelmatigheid van enkelspoorlooplyne deurdat dit die kapasiteit van sulke lyne verhoog in gevalle waar spoorverdubbeling nie finansieel haalbaar is nie.

Werflyne kan gebruik word vir die opstel van treine, rangeerwerk, oorstaan en parkeer van rollende materiaal, en die laai en ontlaai van trokke.

Die spoorlynhiërargie wat hier bo bespreek is, het betrekking op die spoornetwerke wat deur spoorvervoeroperateurs gebruik word. Spoorgoederekarweiers lewer oor die algemeen karweiding op 'n stasiegrondslag. Indien 'n gebruiker van spoorvervoer gebruik maak en spoortoegang tot op sy perseel of by sy bedrywighede vereis, geskied sulke toegang deur middel van 'n private sylyn.

'n Private sylyn is ' $n$ spoor of stel spore wat nie aan die spoorwegonderneming behoort of daardeur bestuur word nie, maar wel gekoppel is aan die spoor van 'n spoorwegonderneming sodat ' $n$ primêre produksiefasiliteit (soos 'n myn), 'n nywerheidsaanleg (soos 'n fabriek of monteeraanleg), 'n kommersiële onderneming (soos 'n groothandelaar), of 'n vervoereindpunt (soos ' $n$ hawe of fisiese verspreidingsentrum) deur 'n spoordiens bedien kan word sonder dat goedereoordrag nodig is. Private sylyne maak dit moontlik dat spoorgoederevervoer 'n perseel-tot-perseeldiens kan lewer, eerder as 'n stasie-totstasie- of 'n eindpunt-tot-eindpuntdiens. Daardeur verhoog dit die toegang tot spoorvervoer sonder dat die oordrag van goederebesendings nodig is. Private sylyne wat gebou is in die tyd toe goederevervoer aan ekonomiese regulering onderhewig was, is deesdae minder nuttig, aangesien talle bedrywe verskuif het en gebruikers steeds spoordienste (veral die vervoer van losmaatgoedere) as van laer gehalte beskou weens niestiptelike diens. Gevolglik bied spoorweë in die algemeen nie meer sylyn-tot-sylyn-diens aan vir die vervoer van deelvragbesendings nie, behalwe in die geval van groot ondernemings wat private sylyne het waarmee hulle aan die spoornetwerk verbind is en voltrokbesendings ontvang en afstuur.

Die oorsprong van trokvragverkeer kan wel private sylyne wees. Drie voorbeelde hiervan is (1) groepverkeer, wat besendings is wat vragkonsolideerders uit verskillende versenders se deelvragbesendings saamgestel het en as ' $n$ enkele voltrokvrag of verskeie voltrokvragte aan die spoor- 
operateur aanbied; (2) verkeer wat verband hou met 'n spesifieke aktiwiteit, soos ' $n$ vervaardigingsaanleg of ' $n$ pakhuis wat losmaatgoedere hanteer, maar dit slegs as voltrokvragte ontvang en versend omdat ' $n$ kort wagtyd en voorraadhoukoste nie van kritieke belang nie; en (3) aanlegte wat vol houers op houertrokke en onverpakte vloeistof met tenktrokke in trokvragtreine na en van verskeie plekke versend en ontvang omdat dit te $\mathrm{min}$ is om eenheidstreine mee te vorm.

Hoewel die aantal private sylyne sedert die ekonomiese deregulering van goederevervoer afgeneem het, is private sylyne deesdae geneig om te vertak in groot werwe wat dikwels toegang bied tot grootmaatspooreindpunte, opryafry-eindpunte en intermodale houereindpunte. In talle lande behoort hawegeriewe nie aan dieselfde onderneming as die spoordiensverskaffer nie, en spoorwerwe by sulke hawens kan dus as kwasi-private sylyne beskou word. Private sylyne kan dus 'n enkele lyn op private eiendom wees waar spoortrokke gebruik word vir die op- en aflaai en tydelike opberging van goedere, of dit kan dien as die aankoms- en vertreklyn vir 'n spoorwerf op private eiendom soos hier bo beskryf, waar eenheidstreine gelaai en afgelaai kan word.

\section{Gevolgtrekkings}

Passasierstasies, veral pendelstasies, is oor die algemeen in stedelike gebiede geleë waar baie passasiers se ritte begin en eindig, en die omliggende grondgebruikspatrone is mensvriendelik. Daarenteen is spoorgoedere-eindpunte toenemend uit digbevolkte stedelike liggings verskuif. Passasierstreine word meesal as eenheidstreine bedryf en bly saamgestel soos wat hulle is. Dit vereis dus minder rangeerbedrywighede en min of geen opstelwerwe nie. In teenstelling daarmee moet spoorgoedere-eindpunte, met uitsondering van eenheidstreineindpunte, aansienlike rangeeraktiwiteite kan huisves. Dit vereis afsonderlike rangeer- en opstelwerfgeriewe. Die hedendaagse siening van die enorme grondoppervlaktes wat spoorgoedereaktiwiteite by eindpunte vereis, is dat dit in digbevolkte stedelike gebiede (1) 'n relatief ondoelmatige vorm van stedelike grondgebruik is; (2) 'n bron van eksterne kosteskepping is vanweë geraas, onooglikheid en dikwels lugbesoedeling, wat as mensonvriendelik beskou word; (3) die voorsiening van aaneenlopende straatnetwerke belemmer; en (4) ' $n$ hindernis is in die weg van toegang tot stedelike geriewe, van die beweeglikheid van stedelinge en van sosiale samesyn.

Spoorvervoeroperateurs lewer oor die algemeen karweiding op 'n stasiegrondslag. Indien 'n gebruiker van spoorvervoer gebruik maak en spoortoegang tot op sy perseel of by sy bedrywighede vereis, geskied sulke toegang deur middel van 'n private sylyn. Hoewel die aantal private sylyne sedert die ekonomiese deregulering van goederevervoer verminder het, vertak private sylyne deesdae in groot werwe wat toegang bied tot groot- maatspooreindpunte, opry-afry-eindpunte en intermodale houereindpunte.

Grootmaatspooreindpunte is geleë by primêre produksieen ontginningspunte en grondstofspesifieke invoerhawens waarvandaan grootmaatgrondstowwe na sekondêre vervaardigings- en verwerkingsaanlegte gekarwei word, of by primêre produksie- en ontginningspunte van waar grootmaatgrondstowwe na sekondêre vervaardigings- en verwerkingsaanlegte en grootmaatspooreindpunte by uitvoerhawens gekarwei word. Grootmaateindpunte by die vertrek- en bestemmingspunt is gewoonlik op ' $n$ private sylyn geleë.

Opry-afry-eindpunte is gewoonlik by ' $n$ in- of uitvoerhawe en op private sylyne by ' $n$ voertuigvervaardigingsaanleg en by 'n streekvoertuigverspreidingsentrum geleë. Hierdie eindpunte benodig 'n groot parkeergebied waar die loonvragvoertuie gehou kan word, veral by streekverspreidingsentrums, wat gewoonlik as hougeriewe dien van waar die streek se kleinhandelafsetpunte bedien word. Streekvoertuigverspreidingsentrums is gewoonlik nie naby sentrale sakegebiede en digbevolkte gebiede geleë nie, maar op plekke waar daar voldoende grondoppervlakte vir die eindpunt se perseel beskikbaar is en waar daar ' $n$ sentrale toegangspadverbinding is met die afleweringsgebied wat dit bedien.

Intermodale eindpunte is gewoonlik geleë by hawens, aansluitstasies en lokuspunte in groot nywerheidsgebiede, weg van sentrale sakegebiede en digbevolkte gebiede.

Hawens: Intermodale eindpunte kan deel wees van 'n hawefasiliteit (aankaai- of nabykaai-sylyngeriewe) waar die goedere-oordrag tussen treine en skepe plaasvind. Op aankaai-sylyne kan goedere-oordrag regstreeks tussen treine en skepe plaasvind, terwyl goedere-oordrag op nabykaaisylyne via ' $n$ opberggerief plaasvind. In beide gevalle loop die hanteringspoorlyne parallel met die kaai/e. Die uitleg hiervan vereis 'n perseel wat tot 50 hektaar kan beslaan, wat meermale meebring dat seegebied aanliggend aan die hawe vir die huisvesting van so 'n nuwe intermodale eindpunt drooggelê moet word en dat daar dikwels verlate ruimtes by sulke hawens ontstaan waar losmaateindpunte voorheen geleë was. Hierdie ontruimde gebiede is gewoonlik vir herontwikkeling beskikbaar.

Aansluitstasies: By hierdie eindpunte word trokke en trokstelle tussen onverenigde houertreine en losvragtreine gerangeer, en daar kan verkeersinteraksie met padvervoer wees. Aansluitstasies is dus toegerus met redelik groot rangeerwerwe en dikwels ook opstelwerwe.

Lokuseindpunte: Alleenstaande binnelandse fokuseindpunte in nywerheidsgebiede is meesal vir padgoederevervoer toeganklik, met elke spooreindpunt wat 'n markgebied van omtrent 'n dag se padgoedere-retoerrit vanaf die eindpunt dek. Lokuspunt-eindpunte kan verbind 
wees met private spoorsylyne (wat wissel van klein sylyne vir ligte houerverkeerbewegings en groot sylyne vir lang maar onverenigde houertreinstelle tot volledige houereenheidstreinsylyne).

Wat die bedryfstoeganklikheid per spoor betref, is in die aflewering wat hierdie artikel voorafgegaan het, aangevoer dat spoorvervoer se primêre rol die karweiding van groot en digte besendings oor lang afstande in plaaslike en streeksmarkte is. Hiervoor bied spoorgoederevervoer dienste in die volgende marksegmente aan: (1) die vervoer van losmaatgoedere wat in voltrokvragte gekonsolideer is; (2) grootmaatvervoer per eenheidstrein van mynbouprodukte, vloeistowwe en graan; (3) opry-afry-dienste per eenheidstrein; en (4) standaard- intermodale houers per eenheidstrein

Op die wyse wat hier bo beskryf is, dra die moderne praktyk van looplyn- en eindpuntplasing vir gebruik deur eenheidstreine, en van sylynplasing en -gebruik om die vervoer van losmaatgoedere aan te bied wat in voltrokvragte gekonsolideer is, daartoe by dat spoorvervoerdienste in nywerheidslande wel 'n diens van punt tot punt, in 'n herontwerpte sin, kan lewer. Net soos wat spoorvervoer niedietoeganklikheidkannadoen watpadgoederekarweiers ten opsigte van die lewering van deelvragvervoer het nie, net so kan padvervoer nie die punt-tot-punt-diensvermoë nadoen wat spoorvervoer in sy modusbesondere voordelige marksegmente het nie.

\section{Verwysings}

Committee of Transport Officials (СОTO), 2017. "Socio-economic analysis of road projects: Technical methods for highways (TMH) 20". Committee Draft CD1. COTO, Pretoria.
Havenga JH, Simpson ZP. 2016. Freight logistics' contribution to sustainability: Systemic measurement facilitates behavioural change. Transportation Research Part $D, 2016,320-331$.

Palmer R. 2011. The railway infrastructure - The most important part of the railway. Available: http://ryan-palmsy.hubpages.com/hub/ (accessed on 27 January 2016).

Pienaar WJ. 2016. The influence of size, location and functions of freight rai terminals on urban form and land use. Corporate Ownership and Control 2016, 13(3): 251-256.

Pienaar WJ. 2018. Goederevervoermodusse wat in internasionale handel gebruik word. Suid-Afrikaanse Tydskrif vir Natuurwetenskap en Tegnologie 37(1): 1-9.

Pienaar WJ. 2019. Goederevervoermarksegmente wat potensieel winsgewend deur spoorvervoer bedien kan word. Suid-Afrikaanse Tydskrif vir Natuurwetenskap en Tegnologie 38(1): 168-179.

RailNetEurope (RNE), 2014. Glossary of Terms Related to Railway Network Statements, 6th edition. RailNetEurope, Vienna.

Railway Technical Web Pages, 2014. Available: http://www.railway-technical.com/ (accessed on 18 August 2015).

Rail yard, 2016. Available: https://en.wikipedia.org/wiki/Rail_yard (accessed on 27 January 2016).

Rickett TG. 2013. Intermodal train-loading methods and their effect on intermodal terminal operations. Thesis submitted in partial fulfilment of the degree of MS in Civil Engineering, University of Illinois at Urbana-Champaign.

Rodrique J-P. 2017. The Geography of Transport Systems, 4th edition. Routledge, London.

Taalburo, SA Vervoerdienste. 1982. Verpakkings- en behoueringswoordeboek. SA Vervoerdienste, Johannesburg.

Taalburo, SA Vervoerdienste. 1985. Lys sinjaal- en treinbedryfsterme. SA Vervoerdienste, Johannesburg.

Taalburo, SA Vervoerdienste. 1982. Lys spoorbaanterme. SA Vervoerdienste, Johannesburg.

Transnet School of Rail. 2014. Functional Yard Operations. Reference FYO_08: Yard Layout. Transnet Freight Rail, Johannesburg.

University of Birmingham and Network Rail. 2011. Railway Lexicon. Reference Rail Lexicon Mark 24, February. University of Birmingham, Birmingham. 